\title{
ANALYSIS OF CONSTRAINTS AND OPPORTUNITIES FOR THE DEVELOPMENT OF SMALLHOLDER COCONUT OIL PROCESSING INDUSTRY IN MICRO ENTERPRISES KONAWE ISLANDS REGENCY
}

\author{
La Rianda Baka $\left.{ }^{1 *}\right)$, La Ode Alwi, Dhian Herdhiansyah"1), Samsul Alam Fyka ${ }^{2)}$, \\ Waode Siti Anima Hisein ${ }^{3)}$ \\ ${ }^{1}$ Department of Food Science and Technology, Faculty of Agriculture, Halu Oleo University \\ ${ }^{2}$ Department of Agribusiness, Faculty of Agriculture, Halu Oleo University \\ ${ }^{3}$ Department of Agrotechnology, Faculty of Agriculture, Halu Oleo University
}

*Corresponding author : rianda.baka@gmail.com

To cite this article:

Baka, L., Alwi, L., Herdhiansyah, D., Fyka, S., \& Hisein, W. (2020). Analysis of Constraints and Opportunities for the Development of Smallholder Coconut Oil Processing Industry in Micro Enterprises Konawe Islands Regency. JIA (Jurnal IImiah Agribisnis) : Jurnal Agribisnis dan IImu Sosial Ekonomi Pertanian, 5(6), 237 - 244. doi:http://dx.doi.org/10.37149/jia.v5i6.14229

Received: September 22, 2020; Accepted: December 30, 2020; Published: December 31, 2020

\begin{abstract}
It is based on the fact that small-scale coconut oil processing in micro-scale businesses is facing serious threats and competition with palm oil produced by large and medium-sized entrepreneurs, resulting in a downturn in business as well as weakening the motivation of coconut farmers to process coconut production into coconut oil. As a result, coconut farmers in their daily lives actually buy palm oil processed by large and medium entrepreneurs, while their businesses are getting worse. In line with this, through this research, an analysis of the obstacles and opportunities for the development of the people's coconut oil processing industry was carried out. The purpose of this study was to analyze the barriers to developing the people's coconut oil processing industry on a micro-scale business and to analyze the opportunities for developing the people's coconut oil processing industry on a micro-scale business. The research method is through a Focus Group Discussion (FGD) to identify obstacles and opportunities for developing the coconut oil processing industry, followed by Analysis Hierarchy Process (AHP) to determine priority problems and priority opportunities that should be carried out by multi-stakeholders for the development of the coconut oil processing industry. The results showed that the priority obstacles to the development of the coconut oil processing industry in micro-scale businesses in Konawe Islands Regency were product marketing problems, financial capital, and business funding problems, production equipment problems, skilled labor issues, raw material problems, micro-business protection policy issues, business organization, and management problems, as well as problems in the use of information technology and innovation. The priority of opportunities for the development of the micro-scale coconut oil processing industry in Konawe Kepualauan Regency is the presence of economic value by-products of coconut oil processing, namely shell charcoal, nata de coco, and coconut coir, there is a tendency for people to consume more coconut oil than consume coconut oil. Palm oil, the existence of a government program to encourage the coconut processing industry, and the nutritional value that is unique to coconut oil. Organizational and business management problems, as well as problems in the use of information technology and innovation. The priority of opportunities for the development of the microscale coconut oil processing industry in Konawe Kepualauan Regency is the presence of economic value by-products of coconut oil processing, namely shell charcoal, nata de coco, and coconut coir, there is a tendency for people to consume more coconut oil than consume coconut oil. Palm oil, the existence of a government program to encourage the coconut processing industry and the nutritional value that is unique to coconut oil. Organizational and business management problems, as well as problems in the use of information technology and innovation. The priority of opportunities for the development of the micro-scale coconut oil processing industry in Konawe Kepualauan Regency is the presence of economic value by-products of coconut oil processing, namely shell charcoal, nata de $\mathrm{coco}$, and coconut coir, there is a tendency for people to consume more coconut oil than consume
\end{abstract}


coconut oil. Palm oil, the existence of a government program to encourage the coconut processing industry and the nutritional value that is unique to coconut oil.

Keywords: coconut oil industry; micro business; opportunities; resistance

\section{INTRODUCTION}

This research is motivated by several facts and conditions that show that the people of Southeast Sulawesi, especially farmers in Konawe Islands Regency, have cultivated coconut plants, especially deep coconuts, known as the People's Coconut conventionally and have been passed down from generation to generation. The traditional coconut cultivation system in the past was more "Top Down" in nature, so it was not based on land suitability studies, the area of coconut cultivation was not designed according to the minimum economic scale so that the farmers lived properly and also the design was not projected as an integrated system with deep processing. the form of downstream products (processed products). As a result, smallholder Coconut farmers remain marginalized and tend to leave and are not interested in cultivating coconut plants. This is reinforced by data showing that in 2011 the number of farmers as many as 467,200 people (45.51\%) of the total workforce in Southeast Sulawesi then decreased to 402,377 people (41.53\%) in 2013 (BPS, 2015).

Another fact, companies that cultivate oil palm on a large scale have entered Southeast Sulawesi which are driven by large entrepreneurs. This fact, on the one hand at a macro level, can bring in and increase local revenue (PAD) and foreign exchange, but on the other hand, on the micro level, it is very threatening to the sustainability of Smallholder Coconut farmers who so far have also contributed to PAD and foreign exchange. The current model of processing people's coconut, apart from being done individually, also very limited to copra or coconut oil on a small scale which actually does not provide benefits for farmers. This is based on the current fact that farmers who traditionally process coconut oil need 4 - 6 coconut seeds with a selling value of IDR 18,000 - IDR 27,000 (coconut price IDR 4,500/ seed) to produce 1 bottle of coconut oil (volume around $650-700 \mathrm{ml}$ ) with a selling price of Rp. 15,000 / $650 \mathrm{ml}$, which is far less competitive than palm oil at Rp. 12,000/900 $\mathrm{ml}$. This fact makes farmers tend to sell coconuts in the form of logs instead of processing them into coconut oil (Kustanto, 1999; La Rianda et al., 2015; Rukmayadi, 2002).

The results of the engineering process of coconut processing technology into various products ranging from processing technology for coconut meat, coconut coir, coconut water to coconut shells, whose application is still limited to large entrepreneurs, but its realization and benefits have not touched the welfare of especially farmers who process oil. small scale coconut. In fact, the facts give a strong indication that coconut oil processors are no longer interested in processing coconut oil. Based on these facts, this study aims to determine the obstacles and opportunities for developing the people's coconut oil processing industry on a micro-scale business.

\section{MATERIALS AND METHODS}

This research was conducted in Konawe Kepulauan Regency which took place from January to May 2020. The selection of the research location was based on the fact that Konawe Kepulauan Regency is one of the centers of smallholder coconut in Southeast Sulawesi. The population in this study were all micro-entrepreneurs who process coconut. into coconut oil.In addition to sampling using a simple random method to participate in Focus Group Discussion (FGD) in identifying obstacles and opportunities for developing the coconut oil processing industry, a purposive (direct appointment) selection of respondents was also carried out based on expertise for data generation needs using the Process Hierarchy Analysis method ( AHP) in order to determine priority obstacles and priority opportunities that should be carried out by multi-stakeholders for the development of the coconut oil processing industry. Primary data collection was carried out by means of a Focus Group Discussion (FGD) to identify obstacles and opportunities for developing the coconut oil processing industry. Furthermore, data collection was carried out using the Process Hierarchy Analysis (AHP) method to determine priority obstacles and priority opportunities for the development of the coconut oil processing industry. Data analysis was carried out by interpreting the results of the FGD and the AHP results associated with the relevant previous research results descriptively. 


\section{RESULTS AND DISCUSSION}

\section{Main Obstacles to the Development of Coconut Oil Processing Industry in Micro Scale Enterprises}

Based on the results of problem identification through FGD, it was found that there were 8 problems that were the main obstacles to the development of the coconut oil processing industry on a micro business scale. The eight problems are analyzed by AHP to determine the priority problems that should be handled by various competent parties in the development of the coconut oil processing industry on a micro-scale business. The FGD results and the AHP results are clearly presented in Table 1.

In Table 1 shows that priority The main problem that should be addressed is the problem of product marketing with a weight value of 0.26 . These results indicate that products made from processed coconut oil from micro-scale businesses are still very difficult to market. This is because policies for protection for micro businesses related to product marketing are still lacking, but also because the entry of modern markets as new messages reaches the village level. The problem related to the difficulty of marketing coconut oil products from micro-scale businesses can be seen in Table 1.

Table 1. Details of the main barriers and priorities for the development of the coconut oil processing industry in micro-scale enterprises

\begin{tabular}{clc}
\hline No. & $\begin{array}{r}\text { Details of the Main Obstacles to the Development of the Coconut Oil } \\
\text { Processing Industry in Micro Scale Enterprises }\end{array}$ & $\begin{array}{c}\text { Priority } \\
\text { (weight) }\end{array}$ \\
\hline 1 & Product Marketing Problems & 0.26 \\
2 & Financial Capital and Business Funding Issues & 0.21 \\
3 & Production Equipment Problems & 0.16 \\
4 & Skilled Workforce Issues & 0.13 \\
5 & Raw Material Issues & 0.10 \\
6 & Micro Business Protection Policy Issues & 0.06 \\
7 & Organizational Problems and Business Management & 0.05 \\
8 & The Problem of Using Information Technology and Innovation & 0.03 \\
\hline
\end{tabular}

Another obstacle faced by coconut oil processing businesses is the lack of funding sources that can be used as business capital for business actors. These obstacles can be overcome through mentoring and strengthening to business actors so that they have the ability to access sacrificial capital. While the lowest obstacle is the use of information technology and innovation with a value of 0.03. This is due to the influence of the development of social media technology which is very easy to access by all people.

\section{Details of the Problem of Marketing of Coconut Oil Products from Micro-Scale Businesses}

Based on the results of problem identification through FGD, it was found that there were 6 problems that caused the marketing of coconut oil products from micro-scale businesses to find difficulties in penetrating the market. The six problems were analyzed by AHP to determine the priority of product marketing problems. The FGD results and the AHP results are clearly presented in Table 2.

Table 2. Details of problems and marketing priorities of coconut oil products in micro-scale enterprises

\begin{tabular}{clc}
\hline No. & \multicolumn{1}{c}{ Details of Coconut Oil Product Marketing Problems in Micro Scale } \\
Enterprises & $\begin{array}{c}\text { Priority } \\
\text { (weight) }\end{array}$ \\
\hline 1 & Product Price Issues & 0.33 \\
2 & Product Packaging Problems & 0.24 \\
3 & Product Storage Problems & 0.18 \\
4 & Problem of Distance of Business Location and Market & 0.12 \\
5 & Micro Business Product Promotion Issues & 0.09 \\
6 & Competitiveness Problems with Similar Products & 0.04 \\
\hline
\end{tabular}

Table 2 shows that the problem of product prices in the form of coconut oil is a top priority problem with a weight value of 0.33 . It can be interpreted that $33 \%$ of the problems in marketing coconut oil from micro-scale businesses are caused by product prices that are not able to compete with other similar products. Cumulatively, the six factors with different priority weight values hamper 
the development of coconut oil processing at a micro scale. This is in line with research (Lestari et al., 2015) stated that the problems of business networks, product innovation and business competition have a positive and significant effect on the development of micro, small and medium enterprises.

\section{Financial Capital and Business Funding Issues}

Based on the results of problem identification through FGD, it was found that there were 5 problems that caused difficulties in micro-scale coconut oil processing businesses in terms of financial capital and business funding. The five problems are analyzed by AHP to determine the priority issues of financial capital and business funding. The FGD results and the AHP results are clearly presented in Table 3.

Table 3. Details of problems and priorities of capital issues and funding for coconut oil processing in micro-scale enterprises

\begin{tabular}{clc}
\hline No. & $\begin{array}{l}\text { Details of Financial Capital Issues and Funding of Coconut Oil Processing in } \\
\text { Micro-Scale Enterprises }\end{array}$ & $\begin{array}{c}\text { Priority } \\
\text { (weight) }\end{array}$ \\
\hline 1 & The Problem of Access to Capital Increase in Financial Institutions & 0.43 \\
2 & Limited capital capacity problem & 0.24 \\
3 & Asset problems that can be used as collateral to financial institutions & 0.18 \\
4 & Limited Sales Result Problems & 0.07 \\
5 & $\begin{array}{l}\text { The problem of the ability to make business books (balance sheet and profit } \\
\text { and loss) }\end{array}$ & 0.07 \\
\hline
\end{tabular}

Table 3 shows that the first priority related to financial problems and business funding is the limited ability of coconut oil processors to access additional business capital at financial institutions with a weight value of 0.43 . This can be interpreted that as much as $43 \%$ of the problems that hinder coconut oil processors in their efforts to develop their business are the limited ability to access capital in financial institutions. This factor is also related to the lack of coconut oil processing assets which can be used as collateral to financial institutions with a weight value of 0.18 . Cumulatively, the five factors that cause coconut oil processors to develop difficulties in developing their business are related to limited financial capital. This is in line with what was found (Suci, 2017) that the weaknesses faced by MSMEs in increasing business capacity are very complex and include various indicators, one of which is interrelated, among others; lack of capital both in quantity and source, lack of managerial ability and skills to operate in organizing and limited marketing.

\section{Production Equipment Problems}

Based on the results of problem identification through FGD, it was found that there were 6 problems related to coconut oil production equipment for micro-scale businesses. The six problems were analyzed by AHP to determine the priority problems of production equipment. The FGD results and the AHP results are clearly presented in Table 4.

Table 4. Details of problems and priorities of coconut oil processing production equipment in microscale enterprises

\begin{tabular}{|c|c|c|}
\hline No. & $\begin{array}{l}\text { Details of Coconut Oil Processing Production Equipment Problems in Micro- } \\
\text { Scale Enterprises }\end{array}$ & $\begin{array}{l}\text { Priority } \\
\text { (weight) }\end{array}$ \\
\hline 1 & The Problem of Ease of Operation of Production Equipment & 0.39 \\
\hline 2 & Affordable Production Equipment Price Issues & 0.22 \\
\hline 3 & The problem of the equipment's ability to produce a higher oil yield & 0.18 \\
\hline 4 & The problem of efficiency and effectiveness of production equipment & 0.09 \\
\hline 5 & Safety Problems Using Production Equipment & 0.08 \\
\hline 6 & Production Equipment Productivity Problems & 0.05 \\
\hline
\end{tabular}

Table 4 shows that the main priority problem for coconut oil processing production equipment is related to the problem of ease of operation production equipment with a weight value of 0.39 , meaning that $39 \%$ of the cumulative production equipment problems are determined by the ease of operation factor. This cannot be denied because on the one hand many coconut oil processing equipment has been produced, but on the other hand, micro-entrepreneurs have not adopted the equipment due to the ease of operation and the unreachable price of the equipment. This is in line with that stated by (Niode, 2009) that khe lack of knowledge on production technology and quality control due to the lack of opportunities to keep up with technological developments as well as lack of education and training are obstacles to micro-business development. 


\section{Skilled Workforce Issues}

Based on the results of problem identification through FGD, it was found that there were 4 problems related to skilled workers in producing coconut oil on a micro scale business. The four problems are analyzed by AHP to determine the priority problems of skilled labor. The FGD results and the AHP results are clearly presented in Table 5.

Table 5 shows that the first priority related to labor issues is workforce experience with a weight value of $0.47(47 \%)$. This indicates that developing a coconut oil processing business on a micro scale requires work experience accompanied by training and courses. The factor of age and education level is the last priority with a weighted value of $0.06(6 \%)$. Even so, age and education level are very important because they relate to the ability to accept technological changes. A relatively young age and a relatively adequate level of education will tend to be more receptive to technological changes than those who are relatively older with limited education.

Table 5. Details of Problems and Priorities for Skilled Coconut Oil Processing Workers in Micro-Scale Enterprises

\begin{tabular}{clc}
\hline No. & Details of the Problem of Skilled Workers in Coconut Oil Processing in Micro- & $\begin{array}{c}\text { Priority } \\
\text { (weight) }\end{array}$ \\
\hline 1 & Workforce Experience Problems & 0.47 \\
2 & Coconut Oil Processing Training and Course Issues & 0.35 \\
3 & Problem The ability to adapt to technological changes & 0.12 \\
4 & Age and Level of Education Issues & 0.06 \\
\hline
\end{tabular}

This is in line with stated by Herawati and Sasana (2013) that work experience, gender and age have a positive effect on labor productivity Micro, Small and Medium Enterprises (UMKM) scale industry.

\section{Raw Material Issues}

Based on the results of problem identification through FGD, it was found that there were 5 problems related to the raw material for processing coconut oil in micro-scale businesses. The five problems were analyzed by AHP to determine the priority of raw material problems. The FGD results and the AHP results are clearly presented in Table 6.

Table 6. Details of Problems and Priorities of Coconut Oil Processing Raw Materials in Micro-Scale Enterprises

\begin{tabular}{clc}
\hline No. & \multicolumn{1}{c}{$\begin{array}{c}\text { Details of Coconut Oil Processing Raw Material Problems in Micro-Scale } \\
\text { Enterprises }\end{array}$} & $\begin{array}{c}\text { Priority } \\
\text { (weight) }\end{array}$ \\
\hline 1 & The Problem of Ease of Obtaining Raw Materials & 0.40 \\
2 & Raw Material Price Issues & 0.28 \\
3 & Raw Material Quality Problems & 0.17 \\
4 & The Issue of Sustainability of Raw Material Supply & 0.08 \\
5 & The issue of the certainty of the amount of raw materials & 0.06 \\
\hline
\end{tabular}

Table 6 shows that the first priority that needs to be handled related to raw material problems is the ease of obtaining raw materials with a weight value of $0.40(40 \%)$. This is triggered by the fact that the coconut cultivation business carried out by each farmer is in a relatively small business scale making it difficult for coconut processors to collect raw materials in relatively large quantities and continuously. Apart from this, the fluctuating factor in the price of raw materials also greatly affects the motivation of coconut oil processors. This is in line with stated by Gea and MM (2018) and lba (2015) that Raw Material Inventory has a significant influence on the Production Process. Raw Material Inventory and Equipment Maintenance together have a significant influence on the Production Process. Cumulatively, the problem of raw materials covers 5 main principles in the fulfillment of raw materials, namely the certainty of the quantity of raw materials, the quality of raw materials, the price of raw materials, the continuity of raw materials and the delivery of raw materials.

\section{Micro Business Protection Policy Issues}

Based on the results of problem identification through FGD, it was found that there were 4 problems related to protection policies for micro-scale businesses. The four problems are analyzed by AHP to determine the priority issues of micro-scale business protection policies. The FGD results and AHP results are clearly presented in Table 7. 
Table 7. Details of problems and priorities for protection policies in micro-scale enterprises

\begin{tabular}{clc}
\hline No. & \multicolumn{1}{c}{ Details of Micro Business Protection Policy Issues } & $\begin{array}{c}\text { Priority } \\
\text { (weight) }\end{array}$ \\
\hline 1 & Funding Policy Issues with Soft Interest & 0.52 \\
2 & $\begin{array}{l}\text { Business Licensing Process Policy Issues } \\
3\end{array}$ & 0.31 \\
Micro Business Development Policy Issues through various government & 0.13 \\
program schemes & $\begin{array}{l}\text { Policy Issues Protection of traditional markets against modern market players } \\
\text { /mini markets }\end{array}$ & 0.05 \\
\hline
\end{tabular}

Table 7 shows that the main priority related to micro-business protection policies is a soft interest financing policy. This occupies the top priority with a weight value of $0.52(52 \%)$ which means that micro-scale coconut oil processing businesses really expect policies regarding soft interest funding because micro-scale coconut oil processing businesses really need funds for business development. The second priority related to the micro business protection policy is a straightforward licensing process with a weight of $0.31(31 \%)$. The last priority related to the protection of microbusinesses is a policy that can protect traditional markets as a marketing for micro-business products from the attacks of modern market players or mini markets Sandi and Maemunah (2019) that. The impact of modern markets on traditional markets is seen in terms of turnover which has decreased turnover, decreased income and the number of customers has decreased quite significantly.

Organizational Problems and Business Management

Based on the results of problem identification through FGD, it was found that there were 5 problems related to the organization and management of micro-scale coconut oil processing. The five problems are analyzed by AHP to determine the priority problems of organization and business management. The FGD results and the AHP results are clearly presented in Table 8.

Table 8. Details of problems and priorities of organization and business management in micro scale coconut oil processing

\begin{tabular}{clc}
\hline No. & \multicolumn{1}{c}{$\begin{array}{c}\text { Description of Organization and Management Problems of Coconut Oil } \\
\text { Processing Business in Micro Scale Enterprises }\end{array}$} & $\begin{array}{c}\text { Priority } \\
\text { (weight) }\end{array}$ \\
\hline 1 & $\begin{array}{l}\text { The problem of the Coconut Oil Processing Micro Business Association } \\
2\end{array}$ & 0.38 \\
2 & $\begin{array}{l}\text { The Problem of Separation of Personal Finance with Coconut Oil Processing } \\
3\end{array}$ & 0.34 \\
4 & $\begin{array}{l}\text { Problem Workances } \\
\text { Business Planning Issues (production, labor, markets and finance) }\end{array}$ & 0.15 \\
5 & Problem Building a network of micro businesses specifically processing & 0.07 \\
coconut oil & 0.06 \\
\hline
\end{tabular}

Table 8 shows that the main priority related to organizational and management problems of coconut oil processing business is the association of coconut oil processing micro enterprises with a weight value of $0.38(38 \%)$. This is driven by the fact that business actors are collectorsCurrently, micro-scale coconut oil does not have a unifying container so it is difficult to compete in the market and it is very easy for modern business actors to manipulate.

\section{The Problem of Using Information Technology and Innovation}

Based on the results of problem identification through FGD, it was found that there were 4 problems related to the use of technology and innovation in micro-scale businesses. The four problems were analyzed by AHP to determine the priority problems in the use of technology and innovation. The FGD results and the AHP results are clearly presented in Table 9.

In the Table 9 shows that the main priority related to the use of technology and innovation is the problem of information systems, especially regarding price changes with a weighted value of 0.47 $(47 \%)$. This is closely related to the interests of micro business actors in knowing early on changes in product prices on the market so that business actors do not become objects that are always disadvantaged due to lack of information on product price changes in the market. The second priority is related to the ability to operate information system applications with a weight value of $0.31(31 \%)$. To anticipate this problem, it is necessary to conduct training on the operation of information system applications for micro-entrepreneurs. This is in line with what is stated by Niode (2009) that the lack of knowledge about marketing, which is caused by the limited information that can be reached by 
MSMEs regarding the market, apart from the limited ability of MSMEs to provide products / services that are in accordance with market desires.

Table 9. Details of problems and priorities for the utilization of coconut oil processing technology and innovations in micro-scale enterprises

\begin{tabular}{clc}
\hline No. & $\begin{array}{c}\text { Description of the Problem of Using Information Technology and Coconut Oil } \\
\text { Processing Innovations in Micro-Scale Enterprises }\end{array}$ & $\begin{array}{c}\text { Priority } \\
\text { (weight) }\end{array}$ \\
\hline 1 & $\begin{array}{l}\text { Information System Issues about Changes in Market Prices } \\
2\end{array}$ & $\begin{array}{c}\text { Problem The ability to operate facilities related to information systems } \\
\text { Problems Using information system applications in business development }\end{array}$ \\
3 & planning & 0.47 \\
4 & Adaptation problems to innovations related to product quality & 0.15 \\
\hline
\end{tabular}

\section{Opportunity for Micro Scale Coconut Oil Industry Development}

Based on the results of the identification of opportunities for the development of the coconut oil processing industry through FGD, it was found that there are 4 components which are opportunities for the development of the Coconut Oil Processing Industry in Micro-Scale Enterprises. The four components of the opportunity are analyzed by AHP to determine the priority components of the opportunity for developing the coconut oil processing industry in micro-scale businesses. The FGD results and the AHP results are clearly presented in Table 10.

Table 10 shows that the main priority associated with the opportunities for developing a micro-scale coconut oil processing industry is the presence of a by-product from coconut oil processing which has economic value with a weight value of $0.43(43 \%)$. This indicates the need for coconut oil processing which is designed in an integrated manner. This is in line with stated by La Rianda Baka (2018) that "the Farmer's positive response as evidenced by the proportion of coconut farmers who agree and strongly agree to the revitalization of coconut plantations and the development of integrated coconut agroindustry not only related to the prospect of financial benefits but also supported by several traditional uses of coconut plants in the form of local wisdom "

Table 10. Details of opportunity components and priority for the development of the coconut oil processing industry in micro-scale enterprises

\begin{tabular}{clc}
\hline No. & $\begin{array}{c}\text { Details of the Opportunity Components for the Development of the Coconut } \\
\text { Oil Processing Industry in Micro-Scale Enterprises }\end{array}$ & $\begin{array}{c}\text { Priority } \\
\text { (weight) }\end{array}$ \\
\hline 1 & There is a by-product of coconut oil processing which has economic value & 0.43 \\
2 & There is a tendency and community culture to consume more coconut oil & 0.34 \\
3 & There is a government program to encourage the coconut processing industry & 0.14 \\
4 & Coconut oil contains a unique nutritional value & 0.09 \\
\hline
\end{tabular}

It is also in line with what is stated by Mahmud, Z., \& Ferry, Y. (2015) that kEliminate a very promising coconut by-product processing business if it is well planned and managed. Based on the financial analysis, it was found that B / C and IRR of coir processing into coir fiber and coir dust were found to be 3.58 and $76 \%$; coconut shell is processed into shell charcoal obtained B / C and IRR of 1.11 and $23 \%$, respectively; and coconut water is processed into nata de coco, the value of $B / C$ is obtained and IRR of 1.32 and $32 \%$, respectively. The development of the by-product processing industry must be supported by technical feasibility, especially the availability of raw material supply and marketing, as well as suitable processing equipment for coir processing. Coir processing must be combined with coir dust processing into compost so that additional income can be obtained. The location for processing by-products should be in the vicinity of the source of raw materials and to ensure continuity of product procurement and marketing, it is recommended that these efforts take the form of a joint venture.

\section{CONCLUSIONS}

The priority problem in the development of the micro-scale coconut oil processing industry in Konawe Islands Regency is the problem of product marketing, while the priority of the opportunity for developing the coconut oil processing industry is the existence of by-products from processing coconut oil which has economic value, namely shell charcoal, nata de coco and coconut husk. 


\section{REFERENCES}

BPS. (2015). Badan Pusat Statistik Sulawesi Tenggara. Kendari. BPS.

Gea, C. N., \& MM, A. S. Y. S. (2018). Pengaruh Persediaan Bahan Baku, Dan Pemeliharaan Peralatan, Terhadap Proses Produksi Dengan Kualitas Bahan Baku Sebagai Variabel Moderating. Media Studi Ekonomi,21(1), 1-12.

Herawati, N., \& Sasana, H. (2013). Analisis pengaruh pendidikan, upah pengalaman kerja, jenis kelamin dan umur terhadap produktivitas tenaga kerja industri shutllecock Kota Tegal Fakultas Ekonomika dan Bisnis].

Iba, Z. R. (2015). Pengaruh Pengendalian Persediaan Bahan Baku Terhadap Kelancaran Proses Produksi Minyak Kelapa di PT. Bireuen Coconut Oil. Jurnal Kebangsaan, 4(8), 39-46.

Kustanto, H. (1999). Sistem Pengembangan Agroindustri Komoditas Unggulan pada Kawasan Andalan: Studi Kasus di Kabupaten Ciamis, Jawa Barat. Institut Pertanian Bogor. http://repository.ipb.ac.id/handle/123456789/4358

La Rianda, B., Hemon, T., \& Pasolon, Y. B. (2015). System Engineering Of Sago Agro-industry Development Using a Regional Approach. Advances in Mathematics and Statistical Sciences,

La Rianda Baka, H. S., La Ode Alwi, Azhar Ansi dan Halijah Koso (2018). A study of community response and determination of priority areas for the application of integrated coconut agroindustry system through the revitalization of coconut plantation and local wisdom for the community of West Muna District. ADRI International Conference on Sustainable CoastalCommunity Development, Sutan Raja Hotel, Kolaka, Indonesia.

Lestari, C., Lubis, N., \& Widayanto, W. (2015). Pengaruh Jaringan USAha, Inovasi Produk Dan Persaingan USAha Terhadap Perkembangan USAha Mikro, Kecil Dan Menengah (Studi Pada IKM Makanan Di Kecamatan Kuningan Kabupaten Kuningan Jawa Barat). Jurnal IImu Administrasi Bisnis 4(2), 185-196.

Niode, I. Y. (2009). Sektor UMKM di Indonesia: Profil, masalah, dan strategi pemberdayaan. \%J Jurnal kajian ekonomi dan bisnis OIKOS-NOMOS 2(1), 1-10.

Rukmayadi, D. (2002). Disain Sistem Penunjang Keputusan Perencanaan Strategi Pengembangan Agroindustri Kelapa Studi Kasus: Kabupaten Ciamis, Jawa Barat Program Pasca Sarjana IPB. Bogor].

Sandi, S. P. H., \& Maemunah, M. (2019). Dampak Pertumbuhan Pasar Modern Terhadap Pasar Tradisional Di Kabupaten Karawang. Buana IImu, 4(1), 72-81.

Suci, Y. R. (2017). Perkembangan UMKM (Usaha mikro kecil dan menengah) di Indonesia. Cano Ekonomos, 6(1), 51-58. 